\title{
In vitro Efficacy of Bacillus spp. against Fusarium oxysporum f. sp. ciceri, the Causal Agent of Fusarium wilt of Chickpea
}

\author{
M. Karthick ${ }^{1 *}$, C. Gopalakrishnan ${ }^{2}$, E. Rajeswari ${ }^{1}$ and V. Karthik Pandi ${ }^{1}$ \\ ${ }^{1}$ Department of Plant pathology, TNAU, Coimbatore-641003, Tamil Nadu, India, \\ ${ }^{2}$ Agricultural College and Research Institute, Kudumiyanmalai, Tamil Nadu, India \\ *Corresponding author
}

\section{A B S T R A C T}

\begin{tabular}{|l|}
\hline Ke y w or d s \\
Chickpea, B. subtilis, \\
$\begin{array}{l}\text { F. oxysporum f.sp. } \\
\text { ciceri, In vitro, } \\
\text { Inhibition }\end{array}$ \\
\hline Article Info \\
\hline $\begin{array}{l}\text { Accepted: } \\
\text { 20 September } 2017 \\
\text { Available Online: } \\
\text { 10 November } 2017\end{array}$ \\
\hline
\end{tabular}

Fusarium wilt of chickpea is a widely distributed and the most destructive disease caused by Fusarium oxysporum f. sp. ciceri. The main objective of this experiment is to identify the effective Bacillus isolates against Fusarium oxysporium f.sp. ciceri under in vitro condition. A total of five Bacillus spp. isolates (TB1, TB2, TB3, TB4 and TB5) were isolated from rhizhosphere region of tomato and eight Bacillus subtilis isolates (BS4, B, KPB5, KK, BSD3, C1, G1, and B2) were collected from Department of plant pathology TNAU, Coimbatore. Totally 13 Bacillus spp. isolates were used for determining their efficacy against Fusarium oxysporum f. sp. ciceri. The Bacillus spp. isolates showed variations in their antagonistic activity against $F$. oxysporum $\mathrm{f}$. sp. ciceri mycelial growth. Among them the isolate B (B. subtilis) showed maximum per cent inhibition of $53.00 \%$ followed by B2 (B. subtilis) (50.10\%), Bacillus subtilis G1 (48.97\%) and Bacillus spp.TB1 (47.77\%).

\section{Introduction}

Chickpea (Cicer arietinum L.) is the third most important pulse in the world, after beans and peas (Vishwadhar and Gurha, 1998). Chickpea (Cicer arietinum L.) is otherwise called as Bengal gram, gram or Spanish pea. They are mainly cultivated in rabi season on marginal lands under rain fed conditions (Shiyani et al., 2001). There are two types of chickpea cultivated globally, first one is desi type another one is kabuli type. Kabuli type shows a larger cream-colored seed with a thin seed coat, desi type is the one type of chickpea has a smaller, reddish browncolored seed with a thick seed coat. The general world production of chickpea consists of about $75 \%$ of desi and $25 \%$ of kabuli types.
Totally 172 pathogens are reported in chickpea crop (Cicer arietinum L.) in different parts of the world (Nene et al., 1996).

The biotic causal agent of chickpea include 67 plant pathogenic fungi, 3 bacteria and 22 plant viruses are reported in chickpea (Nene et al., 1996). Among them, important disease of chickpea is Fusarium wilt caused by Fusarium oxysporum f. sp. ciceri (Nene et al., 1996). It a soil borne pathogen which causes blocking of xylem vessels and wilting (Bateman et al., 1996). Fusarium wilt is the most destructive soil borne disease of chickpea in India (Dileep kumar, 1999). At 
national level it is causing yield losses up to 60 per cent (Singh et al., 2007).

\section{Materials and Methods}

\section{Isolation of pathogen}

Fusarium oxysporum f. sp. ciceri was isolated by tissue segment method on potato dextrose agar medium. The Infected portions from chickpea stem regions were separately collected from farmer's field. They were split vertically for observing presence of vascular discoloration. The infected tissue bits from stem region were cut and surface sterilized using 10 per cent sodium hypochlorite solution for $5-10$ min and subsequently washed three times with sterile distilled water. Then, they were placed in Petri dishes containing potato dextrose agar (PDA) medium and incubated under laboratory conditions at $25 \pm 2^{\circ} \mathrm{C}$ for seven days. In order to obtain pure culture, single spore isolation was performed on PDA medium and maintained as a stock culture for further studies.

\section{Collection and isolation of bacterial antagonist}

The Bacillus isolates (TB1, TB2, TB3, TB4 and TB5) were isolated from the rhizosphere soil of tomato. One gram of rhizosphere soil sample was transferred to sterile test tubes containing $9 \mathrm{ml}$ of sterile distilled water. After they were kept under shaker for 15 minutes, then the suspension mixture was serially diluted in sterile distilled water. One $\mathrm{ml}$ of each $10^{-5}$ and $10^{-6}$ dilutions of bacterial antagonists was pipetted out and poured into sterile Petri plates. Later, $15 \mathrm{ml}$ of nutrient agar media was poured, rotated gently in clockwise and anti-clockwise direction and incubated at room temperature. The isolates of biocontrol agent $B$. subtilis like BS4, B, $\mathrm{KPB}$, $\mathrm{KK}, \mathrm{BSD} 3, \mathrm{C} 1, \mathrm{G} 1$, and $\mathrm{B} 2$ isolates were also obtained from the culture collection section, Department of Plant Pathology. The pure culture of $B$. subtilis isolates were maintained on NA slants at $4^{0} \mathrm{C}$ for further studies (Plate 1).

In vitro testing of Bacillus spp. against $F$. oxysporum f. sp. ciceri (Dual plate method)

Endophytic bacterial strains were tested for their antagonistic activity against mycelial growth of $F$. oxysporum f.sp. ciceri by following the dual culture technique (Dennis and Webster, 1971). Mycelial disc $(8 \mathrm{~mm}$ diameter) of seven days old culture of $F$. oxysporum f. sp. ciceri was placed at one side of the Petri plate containing PDA medium at $10 \mathrm{~mm}$ away from the periphery. Bacterial cultures were streaked onto the medium exactly opposite to the mycelial disc $10 \mathrm{~mm}$ away from the periphery. The plates were incubated under room temperature $\left(30 \pm 2^{\circ} \mathrm{C}\right)$ for 10 days. The effect of the antagonistic organisms against $F$. oxysporum f. sp. ciceri was assessed based on the inhibition zone observed.

The per cent reduction over control was calculated by using the following formula

Per cent inhibition over control $=\stackrel{\text { C }- \text { T }}{-----}$ x 100

Where,

C - Mycelial growth of pathogen in control

$\mathrm{T}$ - Mycelial growth of pathogen in dual plate technique.

\section{Results and Discussion}

The results revealed that all the isolates were effective in inhibiting the mycelial growth of F. oxysporum. f. sp. ciceri. Among these 
isolates, isolate B recorded the maximum per cent inhibition of $53.00 \%$, followed by B2 (50.10 \%), Bacillus G1 (48.97\%) and TB1 $(47.77 \%)$. The control recorded maximum mycelial growth of $90.00 \mathrm{~mm}$ (Table 1; Plate 2).
In the present study, among the thirteen Bacillus spp. isolates tested, the isolates B and B2 were found to show more than 50 percent inhibition over control against the chickpea wilt pathogen $F$. oxysporum f. sp. ciceri under in vitro condition.

Plate 1. Different bacterial antagonistic isolates of Bacillus spp.

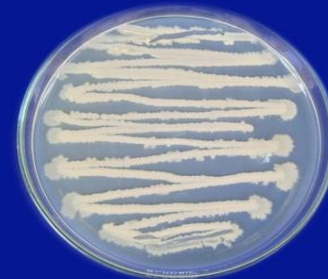

B

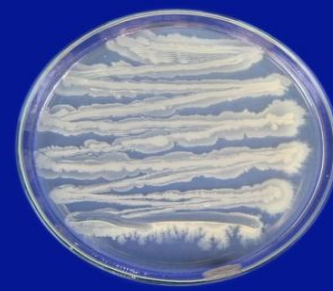

BSD 3

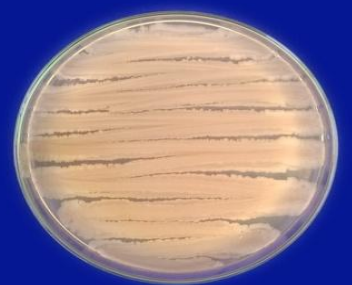

TB 1

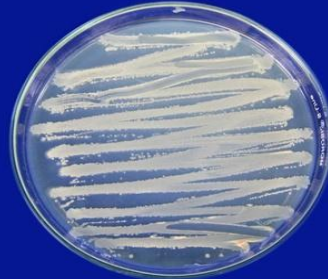

B 2

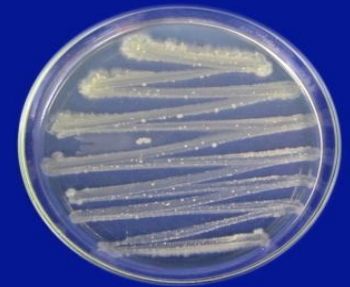

CB6

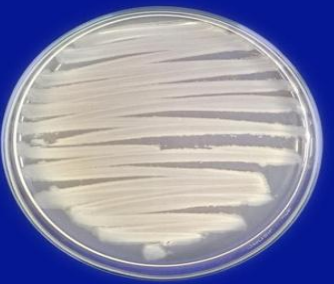

TB 2

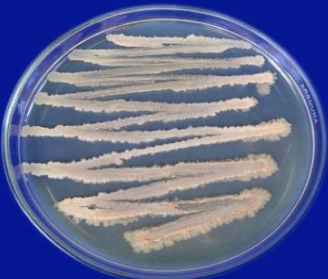

Bacillus G1

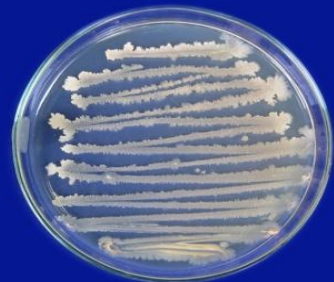

KK

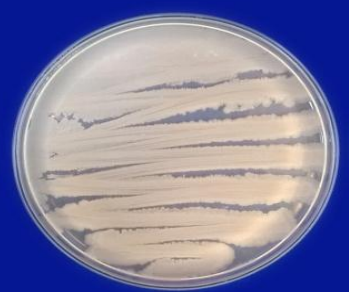

TB 3

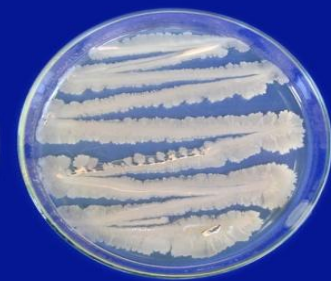

BSC 7

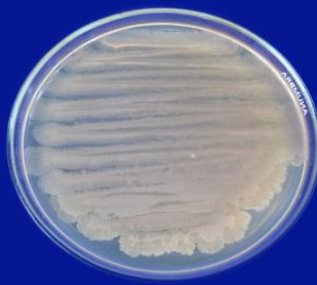

KPB5

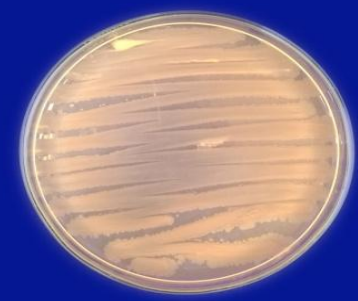

TB 5 
Plate 2. In vitro screening of Bacillus spp. against F. oxysporum f.sp. ciceri

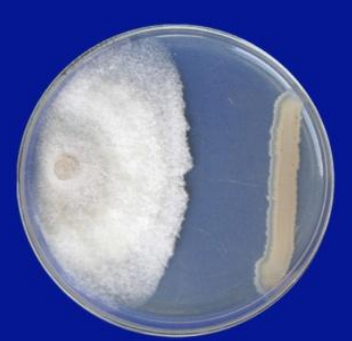

B

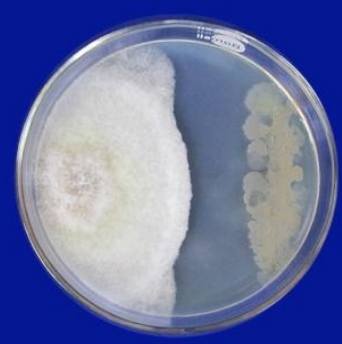

BS 4

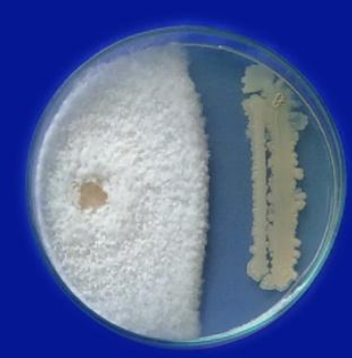

TB 1

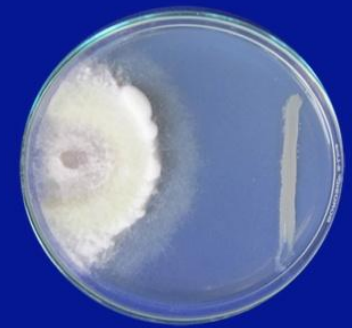

B2

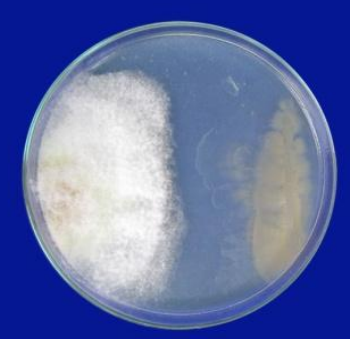

BSD 3

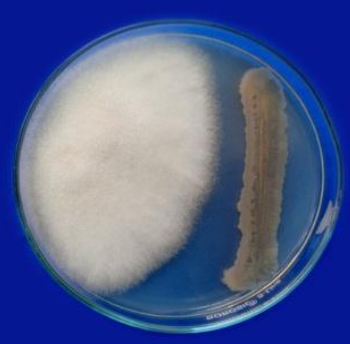

TB 2

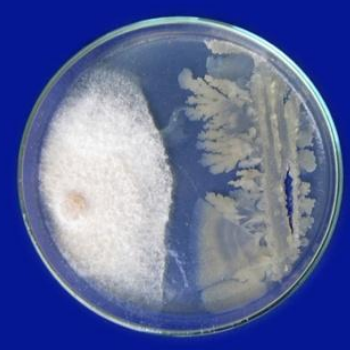

TB 5

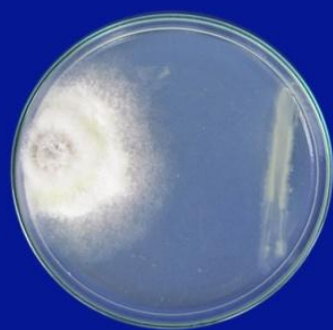

Bacillus G1

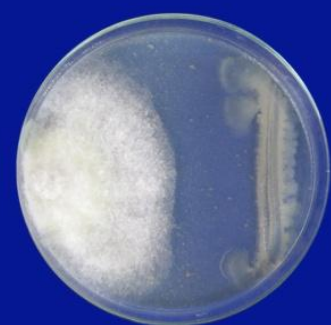

BR 2

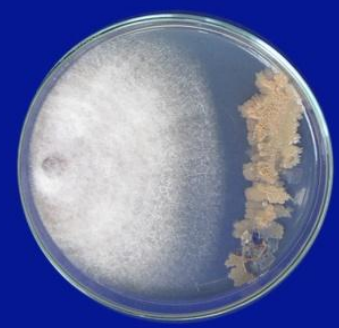

KK

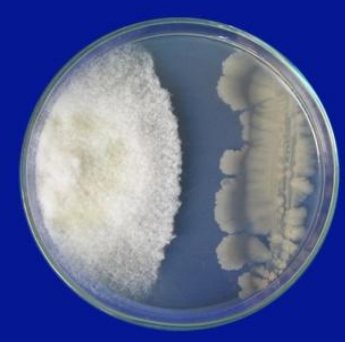

KPB 5

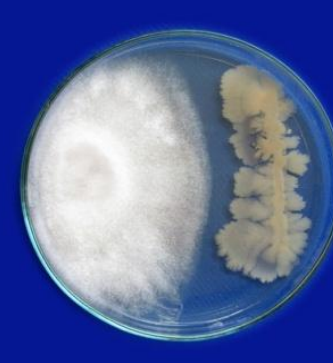

TB 3

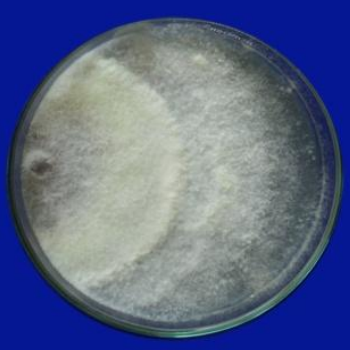

Control

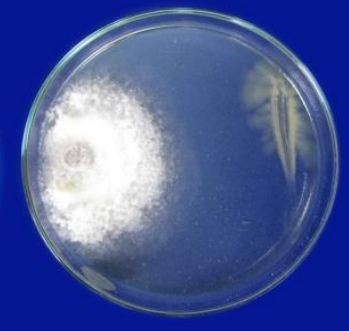

TB 4 
Table.1 In vitro screening of Bacillus spp. against $F$. oxysporum f.sp. ciceri

\begin{tabular}{|c|c|c|c|}
\hline S. No & Isolate & Radial mycelial growth $\mathbf{( m m})^{*}$ & Percent Inhibition over control \\
\hline 1. & Bs4 & $50.37^{\mathrm{ab}}$ & $44.00^{\mathrm{bc}}$ \\
\hline 2. & B & $42.33^{\mathrm{a}}$ & $53.00^{\mathrm{a}}$ \\
\hline 3. & KPB5 & $48.97^{\mathrm{ab}}$ & $45.60^{\mathrm{abc}}$ \\
\hline 4. & KK & $55.47^{\mathrm{abc}}$ & $38.37^{\mathrm{cd}}$ \\
\hline 5. & BSD3 & $48.80^{\mathrm{ab}}$ & $45.80^{\mathrm{abc}}$ \\
\hline 6. & C1 & $49.57^{\mathrm{ab}}$ & $44.90^{\mathrm{bc}}$ \\
\hline 7. & Bacillus G1 & $45.90^{\mathrm{a}}$ & $48.97^{\mathrm{ab}}$ \\
\hline 8. & B2 & $44.90^{\mathrm{a}}$ & $50.10^{\mathrm{ab}}$ \\
\hline 9. & TB1 & $42.00^{\mathrm{a}}$ & $47.77^{\mathrm{ab}}$ \\
\hline 10. & TB2 & $62.00^{\mathrm{bc}}$ & $31.10^{\mathrm{de}}$ \\
\hline 11. & TB3 & $65.33^{\mathrm{c}}$ & $27.43^{\mathrm{e}}$ \\
\hline 12. & TB4 & $55.33^{\mathrm{abc}}$ & $38.53^{\mathrm{cd}}$ \\
\hline 13. & TB5 & $60.00^{\mathrm{bc}}$ & $33.33^{\mathrm{de}}$ \\
\hline 14. & Control & $90.00^{\mathrm{d}}$ & $0.00^{\mathrm{f}}$ \\
\hline
\end{tabular}

*Mean of three replications

Means followed by a common letter are not significantly different at $5 \%$ level by DMRT.

The results are in similarity with the experimental finding of other workers. Zaim et al., (2013) tested Bacillus spp against two F. oxysporum f. sp. ciceri isolates (Foc 1 and Foc2) by dual culture method. The isolates $\mathrm{Rb} 29, \mathrm{Rb} 6, \mathrm{Rb} 12, \mathrm{Rb} 4$, and $\mathrm{Rb} 15$ were the most effective and caused growth inhibition of Foc 1 and Foc2 above $50 \%$ due to the production of volatile metabolites by the rhizobacteria. Karimi et al., (2012) screened 6 isolates of Bacillus against Fusarium oxysporum f. sp ciceri under in vitro.

Among these isolates, B. subtilis B28 isolate showed the highest inhibition percentage $(51.16 \%)$. The inhibitory action may be due to the production of secondary metabolites by the bacterial antagonists and production of antibacterial compounds viz., surfactin, iturin and bacilliomycin (Lambert et al., 1987; Sessitsch et al., 2004). With these evidences, it is predicted that Bacillus isolates might have played a major role in inhibiting the growth of $F$. oxysporum f.sp ciceri by producing the secondary metabolites and antibacterial compounds.

\section{References}

Bateman, G.L., Kwasna, H. and Ward, E. 1996. Relationship among Fusarium spp. estimated by comparing restriction fragment length polymorphism in polymerase chain reaction amplified nuclear DNA. Can J. Microbiol., 42: 1232-1240.

Dennis, C. and Webster, J. 1971. Antagonistic properties of species groups of Trichoderma: Production of nonvolatile antibiotics. Trans. Br. Mycol. Soc., 57: 25-39.

Dileep Kumar, B.S. 1999. Fusarial wilt suppression and crop improvement through two rhizobacterial strains in chickpea growing in soils infested with Fusarium oxysporum f. sp. ciceris. Biol. Fert. Soils, 29(1): 87-91.

Karimi, K., Amini, J., Harighi, B. and Bahramnejad, B. 2012. Evaluation of biocontrol potential of Pseudomonas and Bacillus spp. against Fusarium wilt of chickpea. Aust. J. Crop. Sci., 6(4): 695-703. 
Lambert, B., Leyns, F., Joos, H., Tenning, P., Vas Rijsbergen, R. and Van Outryue, F. 1987. Rhizobacteria of maize and their antifungal activities. Appl. Environ. Microbiol., 53: 1866-1871.

Nene, Y.L., Sheila, V.K., Sharma, S.B. 1996. A world list of chickpea and pigeon pea pathogens $\left(5^{\text {th }}\right.$ Ed. $)$ ICRISAT, Patancheru, Andra pradesh, India, pp 27.

Sessitsch, A., Reiter, B. and Berg, B. 2004. Endophytic bacterial communities of field grown potato plants and their plant growth promoting and antagonistic abilities. Can J. Microbiol., 50: 239349.

Shiyani, R.L., Joshi, P.K. and Bantilan, M.C.S. 2001. Impact of Chickpea Research in Gujarat. ICRISAT,
Patncheru, 50: 23-24.

Singh, G., Chen, W., Rubiales, D., Moore, K., Sharma, YR. and Gan, Y. 2007. Diseases and their management. In Chickpea Breeding and Management (Eds Yadav, Redden, Chen and Sharma). CAB International pp. 497519.

Vishwadhar and Gurha S.N. 1998. Integrated Management of Chickpea Diseases. Integrated Pest and disease management. Rajeev, K., Upadhyay, K.G., Mukerji, B.P, Chamola and Dubey, O.P. (eds.) APH Publishing Co., New Delhi. (India). p. 249.

Zaim, S., Belabid, L. and Bellahcene, M. 2013. Biocontrol of chickpea Fusarium wilt by Bacillus spp. and Rhizobacteria. J. plant prot. Res., 53(2): 177- 183.

\section{How to cite this article:}

Karthick, M., C. Gopalakrishnan, E. Rajeswari and Karthik Pandi, V. 2017. In vitro Efficacy of Bacillus spp. against Fusarium oxysporum f. sp. ciceri, the Causal Agent of Fusarium wilt of Chickpea. Int.J.Curr.Microbiol.App.Sci. 6(11): 2751-2756.

doi: https://doi.org/10.20546/ijcmas.2017.611.325 